\title{
Belorussian-Lithuanian Political and Economic Relations (1990-2015)
}

Zarys treści: Pomimo przynależności Litwy i Białorusi do odmiennych bloków wojskowo-politycznych i sojuszy ekonomicznych, współpraca polityczna i gospodarcza pomiędzy obu państwami rozwija się bez większych napięć i przeszkód. Litwa stara się, aby unijne sankcje wobec Białorusi nie wpływały negatywnie na wzajemne relacje. Z punktu widzenia Mińska litewska polityka zagraniczna była bardziej przewidywalna niż pozostałych sąsiadów należących do NATO i Unii Europejskiej.

Outline of content: Though Lithuania and Belarus belong to two different military, political camps and economic alliances, their political and economic cooperation has seen continuous expansion without any major tensions or disturbances. Lithuania seeks to ensure that EU sanctions don't have a negative impact on their mutual relations. From Minsk's point of view, Lithuanian foreign policy has been more predictable than that of other neighbouring countries belonging to NATO and EU.

Słowa kluczowe: białorusko-litewskie relacje gospodarcze, białorusko-litewskie relacje polityczne, współczesna historia Litwy, współczesna historia Białorusi

Keywords: Belarusian-Lithuanian economic relations, Belarusian-Lithuanian political relations, Belarusian-Lithuanian political relations, contemporary history of Lithuania, contemporary history of Belarus.

As a result of the break-up of the former Soviet Union, the constituent republics that had previously constituted the Union became independent states. Lithuania and Belarus in 1991 became universally recognized as fully-fledged subjects of international relations. Belarusians and Lithuanians had a history of being members of a common state running several hundred years - the Grand Duchy of Lithuania - recognized by each of these nations as their own, as well as the Commonwealth and the Russian Empire which is differently assessed by Lithuanian and Belarusian historiography. In the first years of independence, sentiments and symbols related 
to the distant past played a major role both in Belarus and in Lithuania and negatively influenced the shape of relations between the two states.

In the historiography of independent Belarus, the Grand Duchy of Lithuania was shown as a state having been built mainly by Belarusians. ${ }^{1}$ Aggregate of Russian princes and chiefs who played leading roles in its history over several centuries, predominance of Russian culture, law and writing gave Belarusian historians and journalists the basis for treating the Grand Duchy of Lithuania as one of the stages in their own national tradition. ${ }^{2}$ Vilnius has always been seen as one of the most important centres of national life in Belarusian political thought. The Vilnius Region, which after 17 September 1939 found itself within the so-called Western Belarus, was handed over to Lithuania by Stalin as early as by October the same year. Many intellectuals recognized this province as part of the Belarusian land, which served as the subject of political bargains for the benefit of Soviet state interest. ${ }^{3}$ When the first requests by the republic to secede from the Soviet Union emerged in Lithuania in 1989, Belarusian Soviet authorities in March 1990 suggested their intention to apply for a return of Vilnius and Vilnius Region. ${ }^{4}$

In 1991, independent Republic of Belarus adopted the Vytis, the charging knight, as the state emblem, based on the traditions of the Grand Duchy of Lithuania, which has been used by Belarusian groups and national-independence militias for many decades. This symbolism was a bit different from Lithuanian, but nevertheless, it arose a lot of suspicions in Vilnius, especially as the issue of state borders was still unregulated after the collapse of the USSR.

In Lithuania, both the Vilnius region thesis as a Belarusian ethnic area and the shared legacy of the Grand Duchy of Lithuania were received with concern. ${ }^{5}$ Boundaries between independent republics, which had previously constituted only administrative units of the Soviet Union, needed precise settlement. Many border areas had been subject of dispute, while the disintegration processes in the post-Soviet area had been changing in a very dynamic way. The Belarusian historical narrative in this situation was perceived by some Lithuanians as an instrument for achieving political goals that threaten the integrity of the Lithuanian state. However, most Lithuanian politicians realistically assessed that, regardless of Belarusian historical rhetoric, the existence of an independent Belarus was a factor

1 Гісторыя Беларусі у двух частках, part 1, ed. Я. Новік, Г. Марцуль, Мінск, 1998, pp. 77-99; М. Ермаловіч, Старажытная Літва, Мінск, 1992; А. Кравцэвіч, Гарады і замкі. Беларускага Панямоння. XIV-XVIII стст., Мінск, 1991; id., Стварэнне Вялікага Княства Літоўскага, Мінск, 1998.

2 М. Довнар-Запольский, История Белоруссии, Минск, 2003, р. 58; Энцыьклапедыя гісторыі Беларусі у 6 тамах, vol. 2, еd. Б. Сачанка, Мінск, 1994, pp. 387-423; Нарысы гісторы Беларусі, vol. 1, ed. М. Касцюк, Мінск, 1994, pp. 114-132.

3 3. Шыбека, Нарыс гісторыі Беларусі, 1795-2002, Мінск, 2003, р. 308.

${ }^{4}$ K. Malak, Polityka zagraniczna i bezpieczeństwa Białorusi, Warszawa, 2003, p. 111.

${ }^{5}$ K. Buchowski, Polityka zagraniczna Litwy 1990-2012. Główne kierunki i uwarunkowania, Białystok 2013, pp. 90-91. 
securing Lithuanian independence. The Lithuanians, in addition to Russian domination, were also afraid of Polish claims to the Vilnius Region. The agreement with Belarus was treated as an asset in a possible game with Moscow or Warsaw. ${ }^{6}$

Declaration of independence by Belarus constituted a very important breakthrough in Belarusian-Lithuanian relations. The Belarusian authorities acted as representative of a separate subject of international relations. The new head of state, the chairman of the Supreme Council, Stanisław Szuszkiewicz, was an advocate of building good relations with all the neighbours, he considered the border disputes with Lithuania solvable while preserving existing territorial state of both republics. This was reflected in the "Declaration on the principles of good neighbourly relations between Lithuania and Belarus" signed on 24 October 1991 by the heads of the parliaments of Belarus and Lithuania, Stanisław Szuszkiewicz and Vytautas Landsbergis. ${ }^{7}$ The Declaration had statement on mutual respect for independence and territorial integrity and the urgent need for delimitation of the border, which under the Soviet state had been there only to designate lines of internal administrative units.

However, in Belarusian politics, the border issue with Lithuania has kept returning time and again. At the beginning of 1992, the then foreign Minister, Piotr Krauczanka, in passing said that the Vilnius Region was an ethnically Belarusian area. Adding, however, that any eventual territorial changes expected by Belarus could only be made through negotiations with the Lithuanian side. ${ }^{8}$ Krauczanka's laconic utterance caused a shocking impression on Lithuania, which immediately demanded explanations from the Belarusian counterpart Algirdas Saudargas. Responding to the head of Lithuanian diplomacy, Krauczanka denied that he had asserted any territorial claims against Lithuania. ${ }^{9} \mathrm{He}$, however, did not renounce his opinion concerning the Region, as a Belarusian ethnic area, and consistently demanded recognition of the rights of the Belarusian minority living in Vilnius and the areas around the capital.

Stanislaw Szuszkiewicz, during a visit to Vilnius on 25 March 1992, disavowed all Belarusian territorial claims against Lithuania. The position adopted by the President of the Supreme Council was clearly not in line with government's actions, which expected from the Lithuanian authorities a number of important border adjustments, including return of cross-border railway station in Hoduciszki as well as widening of the water area on the border lake, Dryswiaty.

The visit to Minsk on 14 July 1992 by the Lithuanian Chief of State, Vytautas Landsbergis, which was interrupted by rumours from Vilnius of overturning of the

6 Ibid., p. 90.

7 Декларация от 24 октября 1991 г. "Дэкларацыя аб прынцыпах добрасуседскіх адносін паміж Рэспублікай Беларусь і Літоўскай Рэспублікай”, http://www.levonevski.net/pravo/razdel3/ num2/3d276.html (access: 13 September 2014).

8 B.W., "Białoruś żąda Wilna", Gazeta Wyborcza, 47 (25 February 1992).

9 Buchowski, Polityka zagraniczna Litwy, p. 91. 
government by the opposition had started with great hopes for reaching agreement on all disputes. ${ }^{10}$

At the time, the Belarusian government was seeking to expand its economic contacts with Europe, and had place more hope in Warsaw than Vilniusin this regard. The then Prime Minister, Vyacheslav Kiebicz, seeking a sea window for trade with Western Europe, turned to the Polish government, bypassing Lithuania, whose port in Klaipeda would have been much closer and had infrastructure already adapted for land transport from Belarus to the Baltic coast. In Lithuania this was taken as diplomacy failure of the ruling national camp - Sujūdis, condemning the state to huge economic losses. ${ }^{11}$ It was only after breakdown of dialogue with Poland in 1993 that talks with Lithuania were started, culminating in signing on February 21, 1994 in Minsk of agreement on the use of Lithuanian ports by Belarus by the Prime Ministers: Kiebicz and Valdis Birkavs respectively. ${ }^{12}$

In January 1994, Lithuanian security officials, in consultation with Belarusian officials, arrested former first secretary of the Central Committee of the Communist Party of Lithuania, Mykolasa Burokeviius, and former propaganda secretary of the Communist Party, Juozas Jermalaviius, who were in Belarus. Both had been accused in Lithuania of treason because of their support of Soviet military intervention in Vilnius in January $1991 .{ }^{13}$ Their arrests and extradition to Vilnius took place with the consent of Stanisław Szuszkiewicz. The stance of the head of the Belarusian state, Stanisław Szuszkiewicz, caused the post-communist majority in the in the Supreme Council to mobilize against him. Shuszkiewicz and his closest associates were accused of acting against the state. ${ }^{14}$ Lithuania was accused of practicing state terrorism and of illegal operation of Lithuanian secret services in Belarus. ${ }^{15}$ Szuszkiewicz was subsequently fairly quickly dismissed from the position of President of the Supreme Council.

Resolution of the border issues was reached after the presidential elections in Belarus, followed by signing between 1994 and 1995 of several agreements concerning nationality of disputed towns or objects. In the first years of the presidency of Alexander Lukashenko, relations with Lithuania became quite stable. Contentious border issues were resolved by an agreement signed by Lithuanian and Belarusian Prime Ministers, respectively Adolfas Šleževičius and Mikhail Czyhler after a twoday talk of government delegations in Belarus on 7-8 October 1994. Early 1995, the foreign ministers of the two countries published a document describing precise

10 J. Gorzkowski, "Litwa”, Europa Środkowo-Wschodnia, 2 (1992, published: 1994), pp. 107-108.

11 Buchowski, Polityka zagraniczna Litwy, p. 92.

12 E. Mironowicz, "Białoruś", Europa Środkowo-Wschodnia, 7-8 (1994-1995, published: 1997), p. 296.

13 J. Gorzkowski, “Litwa. Polityka zagraniczna”, Europa Środkowo-Wschodnia, 4-5 (1994-1995, published 1997), p. 132.

14 E. Mironowicz, Białoruś, Warszawa, 2007 (Series: Historia państw świata w XX wieku), pp. 306307.

15 Gorzkowski, Litwa. Polityka zagraniczna, p. 132. 
course of borderline. This eliminated the most important obstacles to normalization of bilateral relations.

In February 1995, Alexander Lukashenko paid a visit to Vilnius, where, together with the Lithuanian President, Algirdas Brazauskas, he signed a "Treaty on good neighbourly relations and cooperation between the Republic of Belarus and Lithuania". ${ }^{16}$ The preamble to the treaty appeals to the centuries-old traditions of good neighbourliness between the Belarusian and Lithuanian nations. The document obliged both parties to do all in their power to prevent their territory from ever becoming a place of action for states, organizations or individuals that could lead to a restriction of sovereignty, territorial integrity or state security of the signatories to the treaty. Each of the signatory countries also undertook to refrain from allowing its territory to be used for armed aggression against the other. In case of aggression of a third country on one of the parties to the treaty, the other undertakes not to provide any assistance to the aggressor. The Treaty guaranteed Belarusian national minorities in Lithuania and Lithuania in Belarus all rights and freedoms in accordance with the spirit of the OSCE documents. The second document signed during Lukashenko's visit to Vilnius was a treaty between the Republic of Belarus and the Lithuanian Republic on location of Lithuanian-Belarusian boundary line, ending rumours that had been circulating concerning this issue. ${ }^{17}$

An intergovernmental agreement was also reached on the use of the Ignalina nuclear power plant that was literally lying on the Lithuanian-Belarusian border. ${ }^{18}$ Belarus leased to Lithuania for 99 years that part of its territory on which contained "Object 500", i.e. a power plant, stood and guaranteed water supplies from Lake Dryswiaty. The railway station in Adutiškis (in Polish: Hoduciszki) was to remain within Lithuania border.

President Alexander Lukashenko set the relations with Lithuania as good example of relations between neighbours, emphasizing that, with goodwill; it is possible to resolve even the most difficult dispute cases. ${ }^{19}$ In July 1995, during the visit of Lithuanian Prime Minister Adolfas Šleževičius in Minsk, talks were undertaken on a very important issue for both Belarus and Lithuania - wider use of the port of Klaipeda for export and import of goods by Belarus.

16 Договор о добрососедстве и сотрудничестве между Республикой Беларусь и Литовской Республикой, http://bankzakonov.com/republic_pravo_by_2010/blockc2/rtf-u5s0a8.htm (access: 23 January 2014).

17 Договор между Республикой Беларусь и Литовской Республикой о белорусско-литовской государственной границе, http://bankzakonov.com/republic_pravo_by_2010/blockc2/rtfu5s0m6.htm (access: 23 October 2014).

18 Соглашение между Правительством Республики Беларусь и Правительством Литовской Республики об "Объекте 500" и ГЭС “Дружба народов", http://bankzakonov.com/republic_ pravo_by_2010/blockc2/rtf-u5s0e9.htm (access: 23 October 2014).

19 “Вытрымка з выступлення прэзідэнта Рэспублікі беларусь А.Р. Лукашэнкі на I Усебеларускім сходзе”, in: Знешняя палітыка Беларусі. Зборнік дакументаў і матэрыялаў (1996-2000), vol. 8, ed. У. Снапкоўскі, Мінск, 2008, p. 82. 
As in the case of relations with Poland, relations between Belarus and Lithuania were influenced by the decisions of the authorities of that country towards to join the North Atlantic Treaty Organization. ${ }^{20}$ In Minsk, this was considered a threat to the security of Belarus. However, in Vilnius it was Lukashenko's determined policy geared towards integration with Russia that was a cause of concern. This worsened the geopolitical position of Lithuania. In 1997, the issue of NATO enlargement to the east was already a foregone conclusion. Belarus's position on this issue remained unchanged. President Lukashenko Belarusian security concept of the countries of Central and Eastern Europe once again presented at the conference of heads of state of the region in Vilnius on 5 September 1997. He argued that NATO on the Belarusian border constituted a new division of the continent. In a situation where no one in Central and Eastern Europe had any territorial claims over another, argued Lukashenko, the safest solution would be to make this region a non-nuclear zone, without any military blocs. ${ }^{21}$ This was a project that has been repeatedly submitted by Belarusian diplomacy ever since it emerged as a sovereign state. Such a solution would probably have suited Russia, but it is difficult to determine whether Lukashenko voiced this idea of his own will or in agreement with the Russian ally, aware that the chances of acceptance of the idea by the countries of Central and Eastern Europe were zero.

Belarus's negative position on NATO expansion and the isolation of Lukashenko's regime on the international stage for violations of human rights and of democratic principles did not worsen the relations between Minsk and Vilnius to the extent it had done on Minsk and Warsaw relations. Lithuania did not join the European Union imposed sanctions on Belarus in 1997, and its leaders did not shy away from contacts with Alexander Lukashenko who is boycotted by the West. ${ }^{22}$ During the visit of Lithuanian President Valdas Adamkus in Belarus on November 12, 1998, both sides recognized each other's right to choose allies, conclude political, economic and military contracts. Such actions undertaken by Lithuania and Belarus - as stated in the communication of the Ministry of Foreign Affairs of Belarus - "should not violate the atmosphere of good neighbourliness and trust in the region". ${ }^{23}$ Therefore, the wording of the communication leads to the conclusion that Belarus had agreed with the inevitable fact of Lithuania's

${ }^{20}$ Gorzkowski, Litwa, p. 132.

21 “Паведамленне МЗС Рэспублікі Беларусь аб удзеле беларускай дэлегацыі на чале 3 прэзідэнтам Рэспублікі Беларусь А.Р. Лукашэнкам у Міжнароднай канферэнцыі “Суіснаванне народаў і добрасуседскія адносіны - гарантыя бяспкі і стабільнасці ў Еўропе”, якая адбылася ў Вільнюсе 5-6 верасня 1997 г.”, in: Знешняя палітыка Беларусі, vol. 8, pp. 137-138.

22 Buchowski, Polityka zagraniczna Litwy, p. 157.

23 “Паведамленне МЗС Рэспублікі Беларусь аб сустрэчы прэзідэнта Рэспублікі Беларусь А.Р. Лукашэнкі з прэзідэнтам Літоўскай Рэспублікі В. Адамкусам, Мінск, 13 лістапада 1998”, in: Знешняя палітыка Беларусі, vol. 8, p. 226. 
accession to NATO, while Lithuania accepted the alliance between Belarus and the Russian Federation.

Contacts at the highest level between Lithuania and Belarus were upheld independently of subsequent sanctions and bans applied by Western states on the most important representatives of the Belarusian authorities. Lithuania was valued by the most important politicians in Minsk for "constructive policy towards Belarus". ${ }^{24}$ Sound political relations were reflected in the size of trade balance. Lithuania was at the forefront of countries with the highest share in economic exchange with Belarus. Most of the goods exported by Belarus to non-European countries were through the port of Klaipeda.

At the end of the twentieth century, many grounds for rise of conflicts and frictions appeared in the relations of Lithuania and Belarus; the countries were at the time moving in opposite directions in geopolitics. In 1999, the Lithuanian authorities granted political asylum to Syamyon Sharetski, chairman of Supreme Council of the parliament dissolved by Lukashenko in 1996, but not recognized by Belarus. In 2000, a radio station with program prepared by Belarusian opposition started broadcasting in Belarusian language from Vilnius. In the same year, BelarusianRussian military manoeuvres were held at the Lithuanian border. Many negative opinions about the other party's actions appeared in the rhetoric of the leaders and commentators of both countries, but they did not entail any serious consequences. ${ }^{25}$

Quite early, the Belarusian government had begun analyzing the consequences of accession of Lithuania and Poland to the European Union and related restrictions on goods exchange and border crossings by Belarusian citizens. However, neighbourhood with the Union was assessed differently than with NATO, the inevitability of obstacles in crossing the western borders was perceived, but the chances of economic development too. Belarus became a transit country between Russia and the big EU market. In Minsk, it was calculated that thanks to the existence of common customs space with Russia, Belarus could become an attractive place to locate European investments and production earmarked for post-Soviet region. ${ }^{26}$

Belarusian policy towards Lithuania was a derivative of relations with Russia and the European Union. Lithuania was keen on reorientation of Belarusian foreign policy on a more pro-Western footing. The Belarusian diplomacy placed quite effectively the geopolitical position of Vilnius for strengthening its position towards Russia and, to a lesser extent, towards the EU.

24 “Паведамленне МЗС Рэспублікі Беларусь аб візіце прэм ер-міністра Рэспублікі Беларусь С.С. Лінга ў Літоўскую Рэспубліку (23 чэрвеня 1999 г.)”, in: Знешняя палітыка Беларусі, vol. 8, pp. 303-304.

25 A. Gubrynowicz, "Litwa", Europa Środkowo-Wschodnia, 11-12 (2001-2002, published 2004), pp. 130-131.

26 “Вытрымка 3 дакумента “Магчымыя наступствы для Рэспублікі Беларусь пашырэння Еўрапейскага Саюза” падрыхтаванага Ўпраўленнем агульнаеўрапейскага супрацоўніцтва МЗС Рэспублікі Беларусь”, in: Знешняя палітыка Беларусі, vol. 8, p. 336-341. 
The Lithuanian authorities, having a realistic prospect of membership of the European Union in 2002, succumbed to Brussels pressure and joined the EU sanctions against Belarus, in so doing demonstrating an extreme form of loyalty towards Western values. Between 2002 and 2004 all Lithuanian-Belarusian political contacts were frozen. There were no meetings at that time even at the level of deputy foreign or parliamentary ministers. It was not until 2005 that the Belarusian Prime Minister paid a visit to Vilnius, and then the Deputy Minister of Foreign Affairs in the year that followed. On the Lithuanian side, after five years of political boycotting of Belarusian authorities, Deputy Foreign Minister made a visit to Minsk. ${ }^{27}$ The presidents met after an 11-year break, that is as late as 2009.

Interstate contacts were maintained by lower level officials and embassy staff. The Lithuanian Embassy in the capital of Belarus mediates, among others, in the relations of NATO management with the Belarusian authorities. Systematic contacts were maintained by representatives of the defence ministries of both countries, who cooperated in the field of air protection, training, military medicine. ${ }^{28}$

The Belarusian authorities reacted to the news of transfer of the seat of the European Humanities University from Minsk to Vilnius in 2005 with pretty restraint. From 1992, the University had been an independent higher education institution funded by EU funds. Due to restrictions by the Belarusian state authorities scientific and teaching activities a decision was made to transfer the university to Vilnius. Formal consent was granted by the Lithuanian government only in 2006, but without any major obstacles the university had been operating since 2005. This issue did not become a cause of friction in bilateral relations, just like "Racja" Radio, program broadcasting from Białystok, didn't in the case of Polish-Belarusian relations.

Before the 2006 presidential election, Lithuanian President Valdas Adamkus met with the main opposition candidate Aleksandr Milinkevich, thus clearly demonstrating political sympathies of the Lithuanian side. The election, according to the State Electoral Commission's communication, was won with a landslide by Lukashenko, but the European Union considered it falsified and introduced economic sanctions against Belarus, excluding it from the group of countries enjoying preferential tariffs in trade with EU. Lithuania, in addition to Poland and Latvia, was against these restrictions. ${ }^{29}$ Officially it was reported that they mostly hit the inhabitants of Belarus, in fact it was feared that the isolation of the country would strongly bind it to Moscow. While it is true that the Lithuanian Parliament adopted

27 А.А. Валодзкін, “Аналіз беларуска-літоўскіх палітычных кантактаў у 2001-2010 гг.”, in: Беларусь в современном мире. Материалы ХІ Международной научной конферениии посвященной 91-летию образования Белорусского государственного университета, Минск, 2012, p. 32-33.

${ }^{28}$ J. Siedlecka-Siwuda, Stosunki między Litwa i Białorusia w okresie Partnerstwa Wschodniego 2008-2010, http://www.psz.pl/Stosunki-miedzy-Litwa-i-Bialorusia-w-okresie-PartnerstwaWschodniego-2008-2010 (access: 10 March 2013).

${ }^{29}$ Ibid. 
a resolution condemning the violation of the democratic elections in Belarus, half of its members did not participate in the vote..$^{30}$ Lithuanian politicians, in order not to worsen the favourable economic relations with Belarus, did not show too great enthusiasm in condemning Belarusian authorities for infringing civil liberties.

In 2008, when the warming-up process in the EU-Belarus relations began, Lithuanian leaders responded the most to the pro-European rhetoric of President Lukashenko. The Belarusian-Russian "gas wars" indicated that the rift between Minsk and Moscow was growing, and Lithuania had a plan to exploit the conflict. At that time, Belarus undertook activities to diversify supply of energy raw materials. The Port of Klaipeda was supposed to be the second largest Venezuelan oil transhipment site beside Odessa, while Lithuania was to be the main transit country for Belarus. In 2008, Belarus became the most important foreign partner of this port, from which about $55 \%$ of transit cargo was shipped (to Russia about $33 \%$, to Kazakhstan about 6\%). ${ }^{31}$ Implementation of projects connected with imports of Venezuelan oil was to increase the importance of Lithuania as a transit country, and in the case of Klaipeda the city gained the opportunity to become the main port in the economic system of Belarus.

Lithuanian-Belarusian contacts gathered momentum after the election of Dalia Grybauskaite as Lithuanian President in May 2009. On her initiative, Alexander Lukashenko visited Vilnius on 16 September 2009. Officially, the visit was held at the invitation of Lithuanian entrepreneurs, during "Belarus Expo 2009" exhibition. Lukashenko was welcomed by the most important representatives of the Lithuanian authorities, indicating that they were keen on dialogue with Belarus leader. The most important issue was that of economic cooperation between the two countries, although both Belarusian and Lithuanian propaganda indicated that Lukashenko's meeting with Lithuanian politicians also served to build Belarusian-EU dialogue. ${ }^{32}$

During his visit in Vilnius "Lukashenko tried to present Belarus as a prospective Lithuanian partner in economic matters. He declared Belarus's support for a highway from the Baltic to the Black Sea, he proposed to the Lithuanians to buy shares in the Naftan refinery and Polimir petrochemical plants, and even for Lithuania to finance its own separate block within Belarusian nuclear power plant to be built $30 \mathrm{~km}$ from Vilnius to gather for own electricity needs. He also offered, after the planned closure of the old nuclear power plant in Ignalina, mediation in transit to Lithuanian of Ukrainian electricity, cheaper and an alternative to the Russian". ${ }^{33}$

\footnotetext{
30 Buchowski, Polityka zagraniczna Litwy, p. 191.

31 J. Hyndle, Wizyta Łukaszenki w Wilnie - dialog polityczny w imię interesów litewskiego biznesu, http://www.osw.waw.pl/pl/publikacje/tydzien-na-wschodzie/2009-09-23/wizyta-lukaszenki-w-wilnie-dialog-polityczny-w-imie-inter (access: 11 March 2013).

32 А. Алехнович, Беларусь-Литва: экономика не зависит от политики, http://www.dw-world. de/dw/article/0,,4701550,00.html (access: 11 March 2013).

33 Hyndle, Wizyta Lukaszenki.
} 
Grybauskaite, addressing Lukashenko, said: "In our words you hear the voice of the European society". Concerning relations with the European Union, Lukashenko responded that Belarus rejects all EU pressures and will pursue its policy according to the interests of the Belarusian people. ${ }^{34}$ Lithuania and Belarus have demonstrated a significant role in bringing the East and West together by building a security and stability zone in the region, but without imposing any foreign solutions and values by any of the parties. ${ }^{35}$

Since 2008, the number of Lithuanian companies in Belarus has been growing rapidly. At the end of the year there were over three hundred. The trade volume has accelerated from month to month, and its value is approaching one billion dollars. ${ }^{36}$ The statement from the Belarusian side shows most of the discussions during Lukashenko's stay in Vilnius were concentrated on joint energy projects and transit of oil from Klaipeda to the refinery in Novopolotsk. ${ }^{37}$ At the level of the ministries concerned, details on implementation of investment plans concerning transmission of electricity from Ukraine to Lithuania were also agreed. A lot was talked on construction of a highway linking the Black Sea with the Baltic Sea, passing through Belarus. A prospect of broad cooperation in the Minsk-VilniusKiev triangle was underway. It had a clear structure aimed at creating a system that would reduce the economic dependence of these countries on Russia. In the case of Belarus, which for many years had led its economy to a high degree of integration with Russia, it was a huge challenge.

The policy of Lithuanian President, Dalia Grybauskaite, who had previously served as EU Commissioner, currently acting as spokesperson for Belarusian interests in Europe, inspired confidence in Minsk and constituted an argument for closer relations with Vilnius. ${ }^{38}$

A more controversial topic in Belarusian-Lithuanian relations was afore-mentioned plan by Belarus to build a nuclear power plant located close to the Lithuanian border, but in a climate of cooperation and moving Belarus closer to the UE, this problem caused less opposition from the Lithuanian side. The scale of planned joint ventures in the field of energy made this project one of many that was supposed to provide Lithuania and Belarus with energy security ${ }^{39}$ In 2010, the

34 “Паведамленне прэс-службы Прэзідента Рэспублікі Беларусь аб візіце прэзідента Беларусі в Літву”, in: Знешняя палітыка Беларусі. Зборнік дакументаў і матэрыялаў (2006-2010 г2.), vol. 10, ed. У. Снапкоўскі, Мінск, 2014, p. 346.

35 Ibid., p. 348.

${ }^{36}$ Siedlecka-Siwuda, Stosunki między Litwa.

37 Паведамленне прэс-службы Прэзідента Рэспублікі Беларусь, р. 349.

38 Ажубалис: Политика ЕС в отночении Беларуси себя оправдала, http://udf.by/news/main news/7518-azhubalis-politika-es-v-otnoshenii-belarusi-sebya.html (access: 9 July 2014); Hyndle, Wizyta Eukaszenki.

39 Change of atmosphere around Belarus after 19 December 2010 implied that Lithuanian evaluation of Belarusian plans to build a nuclear power plant $50 \mathrm{~km}$ away from Vilnius assumed a different shape. The head of Lithuanian diplomacy, Audronius Ažubalis, called it a provocation 
intergovernmental relations were so good that the cultural ministries of the two countries agreed on a joint project to produce a film about the Battle of Žalgiris (in Polish: Grunwald). ${ }^{40}$

However, both countries focused mainly on economic cooperation. ${ }^{41}$ It was coordinated by the prime ministers, Andrius Kubilius and Siarhiej Sidorski. The Lithuanian Prime Minister even spent his vacation in July 2010 in Belarus, using his vacation time to agree on a better adaptation of the port of Klaipeda to serve Belarusian trade, especially the transit of Venezuelan oil.

The Lithuanians, driven by their own interests, were forced to persuade Minsk to include Klaipeda as the main port serving the Belarusian trade. Latvian and Estonian ports constituted competition for Klaipeda. This gave the Belarusian authorities a broad opportunity to negotiate the cost of transit services. Lithuania strengthened its economic offer by offering Lukashenko political support and mediation in negotiations with the European Union. According to Joanna Hyndle, Lithuania risked a lot "committing itself clearly on side of Belarusian president, having no guarantee of future economic benefits, or whether its political support would translate into a prestigious success for the country in the process of democratization of for Belarus". 42

On an official visit of Dalia Grybauskaite in Minsk in October 2010, she expressed her willingness to lend help from Lithuania side to "make Belarus more open and respected in Europe". ${ }^{43}$ With particular acknowledgement, she pointed out Belarusian president's efforts to achieve the country's energy independence and promised her support to this end. On behalf of the European Union, she demanded preservation of democratic procedures during the presidential elections that were scheduled for 19 December 2010.4

President Lukashenko dispelled all of Lithuanian fears with assurances of fair and democratic presidential elections. Both sides were of the idea that the most important for their national interests were the economic matters. ${ }^{45}$ The signing of an agreement on low border traffic that allowed crossing the border without visas by the citizens of both countries living in the 50-kilometre strip on each side of the border constituted a confirmation of Lukashenko's willingness to extend the

\footnotetext{
against Lithuania: Кіраўнік МЗС Літвы: Рашэнне Беларусі пабудаваць АЭС за 50 км ад Вільнюса з'яўляецияа правакацыяй, http://belapan.com/archive/2011/04/08/eu_eu_462348_462353/ (access: 9 July 2014).

40 Siedlecka-Siwuda, Stosunki między Litwa.

41 Алехнович, Беларусь-Литва.

42 J. Hyndle, Litwa konsekwentnie zacieśnia wspótpracę z Białorusią, http://www.osw.waw.pl/pl/ publikacje/tydzien-na-wschodzie/2010-10-27/litwa-konsekwentnie-zaciesnia-wspolprace-z-bialorusia (access: 9 July 2014).

43 Паведамленне прэс-службы Прэзідента Рэспублікі Беларусь, р. 468.

44 Ibid., p. 469.

45 Беларусь-Литва: самый высокий прирост среди грузов в Клайпедском порту - из Беларуси, http://www.ctv.by/news/ news=46315 (access: 9 July 2014).
} 
cooperation. ${ }^{46} \mathrm{He}$ also proposed to the Lithuania side a joint building of a nuclear power plant that would safeguard the energy needs of both countries. ${ }^{47}$

After 19 December 2010, while it is true that relations with Lithuania did undergo fundamental changes, atmosphere in the bilateral relations did not changed. President Grybauskaite did not share the opinion of most EU politicians on the need to introduce sanctions against the Lukashenko regime and de-facto international isolation of Belarus. She rejected domestic and foreign charges of overly close cooperation with the Belarusian dictator. ${ }^{48}$ More than anything else, Lithuania did not want to lose the enormous chance of a transit country and projected revenues that could result from the operation of Belarusian trade with overseas countries. ${ }^{49}$ Her predecessor, Valdas Adamkus, call the policy towards Belarus a catastrophe. ${ }^{50}$

In 2011, Lithuanian dignitaries joined the verbal criticism of the Belarusian authorities for violation of democracy and human rights, but they supported business in expanding economic contacts, hence in reality they boycotted EU sanctions. In September 2011, the Lithuanian government abolished visa fees for entry into Lithuania. Consular offices in Minsk and Grodno issued in that same year 150 thousand visas to the Schengen area. ${ }^{51}$ The following year, Lithuanian diplomats lobbied in Brussels to ease entrance to the EU by Belarusian citizens. ${ }^{52}$

In 2010, the value of trade flows between Lithuania and Belarus was $\$ 0.8$ billion, in 2011: $\$ 1.3$ billion, in 2012: $\$ 1.6$ billion. ${ }^{53}$ Belarus had a positive balance. Doubling of turnover took place shortly after new sanctions were announced by EU. More than $26 \%$ of goods exported by ships from Klaipeda port in 2012 came from Belarus.

In 2015, turnover dropped to $\$ 1.2$ billion. The value of Belarusian exports to Lithuania amounted to 964 million, while the imports amounted to 278 million. ${ }^{54}$

${ }^{46}$ Hyndle, Litwa konsekwentnie zacieśnia współpracę.

47 Паведамленне прэс-службы Прэзідента Рэспублікі Беларусь, р. 471.

48 Грибаускайте: катастрофа - десятилетняя изоляция Беларуси, http://afn.by/news/i/146525 (access: 3 January 2015); В. Вілейта, Літва - за вяртанне Беларусі ў Еўропy, http://www. dw-world.de/dw/article/0,,4056465,00.html (access: 9 July 2014).

49 Литва за политические санкции против белорусских властей, сомневается по поводу экономических ограничений, http://www.interfax.by/news/belarus/86303 (access: 9 July 2014).

50 Адамкус: внешняя политика Литвы в отношении Беларуси - это катастрофа, http:// ru.delfi.lt/news/politics/adamkus-vneshnyaya-politika-litvy-v-otnoshenii-belarusi-eto-katastrofa.d?id=40330863 (access: 9 July 2014).

51 А.В. Тихомиров, Белорусско-литовские отношения на современном этапе, in: Актуальные проблемы международных отночений и дипломатии (вторая половина XX - начало XXI в.). Материаль международной научо-практичной конференции, еd. А.В. Тихомиров, Витебск, 2013, p. 190.

52 Беларусь и Литва: сквозь дебри истории и политики, http://eurocenter.by/analitics/belarusi-litva-skvoz-debri-istorii-i-politiki (access: 1 April 2016).

53 Тихомиров, Белорусско-литовские отношения, рр. 190-191.

54 Иностранные совладельиы сети “Ома" зарезервировали 50 млн евро для инвестииий в Беларусь, http://news.tut.by/economics/489524.html (access: 3 April 2016). 
Petroleum products dominated in the structure of exported goods. As a result of drastic reduction of oil prices on world markets, the value of Belarusian exports was affected too.

A separate category in the balance of trade between the two countries was the exchange of services, whose value in 2015 was $\$ 1.4$ billion. ${ }^{55}$ Balance in this area was definitely in favour of Lithuania due to its port and rail services.

Klaipeda Port has in fact become a strategic object for the economies of both countries. For Belarus, it is the closest and cheapest access to the sea, while it brought significant revenue to the budget for Lithuania. Besides, the Lithuanians did everything to be more competitive than Latvian and Estonian ports, selling shares of ownership of some transhipment terminals or establishing joint shipping companies serving freight traffic between Belorussia and Klaipeda.

Relations between the two countries were quite well characterized by Russian commentator Vadim Volosh who noted that "Lithuanian-Belarusian relations are the hostages of "bigger brothers" - Moscow and Brussels. Russia suspiciously treats the Eastern Partnership with EU and closely monitors in order to make sure Minsk does not re-orient itself towards the West. The European Union, on the other hand, flounders between a sanction policy and rational approach to relations with Belarus, while Lithuania, as a member of the EU aspiring to be an intermediary between Minsk and Europe, cannot simply ignore the position of Brussels. On the other hand, however, it is very active in favour of the democratization of Belarus, and this irritates A. Lukashenko who from time to frighten the Lithuanians, for example, that he will divert Belarusian goods to ports of other countries". ${ }^{56}$ Lithuanian diplomats have often been forced to explain, in a convoluted way, how it is that Vilnius is concerned about the issue of respect for human rights in Belarus, seeing the rapidly growing flow of Belarusian goods moving through Lithuania. ${ }^{57}$

The affiliation of Lithuania and Belarus with different military-political blocs and economic alliances has not hampered development of economic cooperation and the maintenance of relatively good bilateral relations. Economic as well as political interests have on several occasions forced the Lithuanian authorities to distance themselves from the EU's policy of sanctions against Belarus. From Minsk's point of view, the Lithuanian foreign policy has been more compromising and predictable than that of the remaining NATO and European Union neighbours.

55 Ibid.

56 В. Воловой, Литовско-белорусские отношения - между выгодой и иенностями, http://inosmi.ru/sngbaltia/20130521/209206888.html (access: 3 April 2016).

57 Ibid. 


\section{Belorussian-Lithuanian Political and Economic Relations (1990-2015) Abstract}

During the first years of their independence a pivotal role in mutual relations of Lithuania and Belarus was played by historic symbols related to their many centuries-old belonging to one state - the Grand Duchy of Lithuania. For many years there was a problem of un-demarcated border between the two countries. But leaders of the two countries were flexible and compromise, so all the thorny issues were resolved without special incidents.

The accession of Lithuania to NATO and the European Union as well as association agreements between Belarus and the Russian Federation were factors hindering the bilateral relations. The EU's sanctions against Minsk obliged Vilnius to restrict its contacts and cooperation with Belarus. Lithuanian's leaders sought to preserve some margin of independence and maintained the development of economic relations with Belarus. For Minsk, Lithuania was very important due to the port of Klaipeda through which a majority of its goods exported and imported by the sea were transported.

The fact that Lithuania and Belarus belong to different military political camps and economic alliances hampers neither their economic cooperation nor fairly good bilateral relations. Due to its economic and political interests, Lithuania was forced several times to distance itself from the policy of the EU towards Belarus. From the perspective of Minsk, Lithuanian foreign policy was more predictable than of other neighbouring countries belonging to NATO and EU.

\section{Белорусско-литовские политические и экономические отношения (1990-2015)}

\section{Аннотация}

В первые годы независимости Литвы и Белоруссии большую роль в двусторонних отношениях играли исторические символы, связанные с многовековой принадлежностью обеих республик общему государству - Великому Княжеству Литовскому. Многие годы проблемой оставалась неурегулированная линия разграничения. Лидеры обеих стран проявили много склонности к компромиссам и все спорные вопросы были урегулированы без больших инцидентов. Вступление Литвы в НАТО и Европейский Союз, а также союзные договоры Белоруссии с Российской Федерацией были факторами, усложнявшими двустороннее сотрудничество. Санкции Евросоюза против Минска обязывали Вильнюс ограничить контакты и сотрудничество с Белоруссией. Однако литовские власти пытались сохранить предел самостоятельности и постоянно поддерживали, по меньшей мере, экономические отношения с Белоруссией. В случае Минска, Литва имеет огромное значение из-за порта в Клайпеде, через который Белоруссия экспортирует и импортирует большинство товаров, отправляемых морским путем.

Принадлежность Литвы и Белоруссии к противоположным военно-политическим блокам и экономическим союзам не стала помехой в развитии экономического сотрудничества и сохранении в меру корректных двусторонних отношений. Экономические, а также политические интересы несколько раз принуждали литовские власти дистанцироваться от политики санкций ЕС в отношении Белоруссии. С точки зрения Минска литовская внешняя политика была более компромиссной и предсказуемой чем остальных соседей - членов НАТО и Европейского Союза. 


\section{Bibliography}

Buchowski K., Polityka zagraniczna Litwy 1990-2012, Białystok, 2013.

Gorzkowski J., "Litwa”, Europa Środkowo-Wschodnia, 2 (1992, published: 1994).

Gorzkowski J., "Litwa. Polityka zagraniczna”, Europa Środkowo-Wschodnia, 4-5 (1994-1995, published: 1997).

Gubrynowicz A., "Litwa”, Europa Środkowo-Wschodnia, 11-12 (2001-2002).

Hyndle J., Litwa konsekwentnie zacieśnia wspótpracę z Białorusią, http://www.osw.waw.pl/pl/ publikacje/tydzien-na-wschodzie/2010-10-27/litwa-konsekwentnie-zaciesnia-wspolpracez-bialorusia.

Hyndle J., Wizyta Łukaszenki w Wilnie - dialog polityczny w imię interesów litewskiego biznesu, http://www.osw.waw.pl/pl/publikacje/tydzien-na-wschodzie/2009-09-23/wizyta-lukaszenkiw-wilnie-dialog-polityczny-w-imie-inter.

Malak K., Polityka zagraniczna i bezpieczeństwa Białorusi, Warszawa, 2003.

Mironowicz E., “Białoruś”, Europa Środkowo-Wschodnia, 7-8 (1994-1995, published: 1997).

Mironowicz E., Białoruś, Warszawa, 2007 (series: Historia państw świata w XX wieku).

Siedlecka-Siwuda J., Stosunki między Litwa i Białorusią w okresie Partnerstwa Wschodniego 2008-2010, http://www.psz.pl/Stosunki-miedzy-Litwa-i-Bialorusia-w-okresie-PartnerstwaWschodniego-2008-2010.

Алехнович А., Беларусь-Литва: экономика не зависит от политики, http://www.dw-world. $\mathrm{de} / \mathrm{dw} /$ article/0,,4701550,00.html.

Валодзкін А.А., “Аналіз беларуска-літоўскіх палітычных кантактаў у 2001-2010 гг., in: Беларусь в современном мире. Материаль ХІ Международной нащчной конферениии посвященной 91-летию образования Белорусского государственного университета, Минск, 2012.

Воловой В., Литовско-белорусские отношения - между выгодой и иенностями, http:// inosmi.ru/sngbaltia/20130521/209206888.html.

Довнар-Запольский М., История Белоруссии, Минск, 2003.

Ермаловіч М., Старажытная Літва, Мінск, 1992.

Кравцэвіч А., Гарады і замкі Беларускага Панямоння, Мінск, 1991.

Кравцэвіч А., Стварэнне Вялікага Княства Літоўскага, Мінск, 1998.

Тихомиров А.В., “Белорусско-литовские отношения на современном этапе”, in: Актуальные проблемы международных отношений и дипломатии (вторая половина XX - начало XXI в.). Материалы международной научо-практичной конференции, еd. А.В. Тихомиров, Витебск, 2013.

Шыбека 3., Нарыс гісторыі Беларусі, 1795-2002, Мінск, 2003.

Eugeniusz Mironowicz, Prof. Dr. Hab., Head of the Department of International Politics at the Institute of History and Political Science, University of Bialystok. Research interests: foreign policy of post-Soviet countries, recent history of Belarus, ethnic problems in Eastern European countries. Author of among others: Polityka zagraniczna Białorusi 1990-2010 (Białystok, 2011); Polityka zagraniczna Ukrainy 1990-2010 (Białystok, 2013); Wojna wszystkich ze wszystkimi. Białoruś 1941-1944 (Kraków, 2015) (ebma@interia.pl). 